\title{
TEMPAT KETIGA BERKONSEP RUANG TAMU BAGI KAWASAN PENJARINGAN DENGAN EKSTENSI SKYWALK SEBAGAI PRASARANA PENDUKUNG MOBILITAS PEDESTRIAN PADA SKALA LINGKUNGAN
}

\author{
Daniel Yohanes ${ }^{1)}$, Priscilla Epifania ${ }^{2)}$ \\ 1)Program Studi S1 Arsitektur, Fakultas Teknik, Universitas Tarumanagara, danielyohanes90@yahoo.com \\ 2)Program Studi S1 Arsitektur, Fakultas Teknik, Universitas Tarumanagara, priscillae@ft.untar.ac.id
}

Masuk: 14-07-2020, revisi: 01-08-2020, diterima untuk diterbitkan: 24-09-2020

\begin{abstract}
Abstrak
Third place berperan sebagai wadah berkumpulnya warga di luar keseharian mereka tinggal dan bekerja, dan dapat meningkatkan kualitas kehidupan masyarakat perkotaan, terutama di dalam era yang semakin individualis sebagai akibat dari perkembangan teknologi. Kawasan Penjaringan memiliki salah satu noda teramai di Kota Jakarta, dan terdiri dari perumahan (tempat pertama) dan perkantoran (tempat kedua) dengan presentase yang relatif besar dan seimbang, dengan posisi yang memungkinkan adanya permeabilitas di antara keduanya. Tapak perancangan yang terletak di perbatasan Kelurahan Pluit dan Kelurahan Penjaringan, terpilih berdasarkan investigasi kawasan yang dilakukan. Beberapa fasilitas terdekat memiliki potensi peningkatan kualitas, diantaranya Taman Putra Putri, Halte Transjakarta Penjaringan, dan Mal Pluit Junction. Sebuah skywalk dihadirkan untuk mengkoneksikan fasilitas-fasilitas tersebut dengan menjad wadah yang membawa pergerakan dari dan menuju ke Halte Transjakarta Penjaringan untuk menghidupkan Mal Pluit Junction serta Taman Putra Putri yang pada kondisi eksisting tidak berfungsi secara maksimal. Tempat ketiga yang dirancang terhubung dengan skywalk ini dan menjadi sebuah kesatuan bagi konektivitas yang terbentuk. Musik merupakan tema terpilih sebagai pengikat orang-orang yang beragam latar belakangnya. Teori proksemik dan metode Bahasa Pola digunakan untuk menciptakan keruangan yang mendorong terjadinya interaksi sosial. Visi proyek ini adalah untuk menjadikan tempat ketiga ini "sebuah ruang tamu besar" bagi Kawasan Penjaringan. Tempat ketiga yang memberikan kebebasan ekspresi dan mengundang pengunjung untuk membawa dan memainkan instrumen musik ini diharapkan dapat berperan sebagai wadah interaksi dan kegiatan bagi warga lokal ataupun pengunjung dari luar kawasan.
\end{abstract}

Kata kunci: kebebasan ekspresi; musik; ruang tamu; skywalk; tempat ketiga

\begin{abstract}
A third place functions as a meeting platform for people outside their daily routine in homes, working places, and can enhance the life quality of urban society, especially during the increasingly individualist era due to the growth of technology. Penjaringan District has one of the busiest nodes in Jakarta City, and consists of housing (first place) and offices (second place) with relatively large and equal percentage, and with the positions which allows permeability. The design site which is located between Pluit and Penjaringan Subdistricts, is chosen based on the performed district investigation. Nearby facilities have the potential to be improved, such as Putra Putri Park, Penjaringan Busway Station, and Pluit Junction Mall. A skywalk is introduced to connect the facilites by acting as a platform to bring mobility from and to Penjaringan Busway Station to vitalize Pluit Junction Mall and Putra Putri Park which in their existing condition did not function as intended. The designed third place which is connected with the skywalk becomes one with the formed connectivity. Music is the chosen theme for the third place as a binder of the people with their differing backgrounds. The proxemics approach and the Pattern Language method are used to shape the spaces to encourage social interaction. The vision is to make the third place to be "a large living room" for Penjaringan District. The third place which provides a freedom of expression and encourages visitors to bring and play music instruments is hoped to act as an interaction and activity platform for both the locals and outsiders.
\end{abstract}

Keywords: freedom of expression; living room; music; skywalk; third place 


\section{PENDAHULUAN}

\section{Latar Belakang}

Kota Jakarta merupakan kota yang berkompleksitas tinggi dengan masyarakat yang beranekaragam latar belakangnya. Kota Jakarta memiliki noda-noda yang ramai dengan aktivitas dengan lokasi yang tersebar, salah satunya yaitu Kawasan Penjaringan (BPS, 2019). Kawasan ini memiliki fasilitas-fasilitas yang beragam berdasarkan fungsinya, dan didominasi dengan perumahan sebagai tempat pertama serta perkantoran sebagai tempat kedua. Dari pemetaan yang dilakukan terlihat adanya potensi dihadirkannya sebuah sarana penghubung di pusat kawasan. Kawasan ini dengan tingkat kesibukan warganya yang tinggi dalam konteks era individualis akibat dari perkembangan teknologi membutuhkan sebuah wadah untuk bersosialisasi di tengah kesibukan dalam keseharian mereka. Wadah ini diharapkan dapat menjadi ruang publik yang memiliki program dan tema pengikat sebagai sebuah tempat ketiga (Oldenburg, 1989). Salah satu tema yang dikenal sebagai pengikat antar manusia adalah musik, dan pernyataan ini didukung dengan adanya beberapa penelitian yang menunjukkan hal tersebut (Mehr et al., 2019).

Keberhasilan sebuah tempat ketiga sebagai bagian dari keseharian warga bergantung pada variasi aktivitas yang ditawarkan (PPS, 2008) serta pengalaman yang dihasilkan oleh kualitas ruang-ruang di dalamnya (Tuan, 1977). Pengalaman keruangan ini menjadi sebuah kesatuan dengan pengalaman mobilitas manusia dalam konteks urban (De Certeau, 1988). Keruangan untuk tempat ketiga ini dapat dibentuk dengan menggunakan metode yang mempertimbangkan pola perilaku manusia ketika berinteraksi dengan ruang-ruang yang berbeda (Alexander, 1977).

\section{Rumusan Permasalahan}

Fasilitas-fasilitas yang ada di sekitar tapak perancangan di pusat Kawasan Penjaringan tidak berfungsi secara maksimal dalam aspek pergerakan dan intensitas penggunaannya. Selain itu, ramainya noda Kawasan di dekat tapak perancangan menunjukkan potensi peningkatan kualitas lingkungan dan warganya jika dihadirkan sebuah tempat ketiga, yang dapat berperan sebagai wadah kegiatan di luar keseharian warga Kawasan Penjaringan, terutama bagi mereka yang melakukan kegiatan di tempat pertama dan tempat kedua yang ada di dekat tapak perancangan.

\section{Tujuan}

Penelitian ini bertujuan untuk menghadirkan sebuah tempat ketiga yang melayani warga Kawasan Penjaringan serta meningkatkan kualitas lingkungan sekitarnya secara keseluruhan berdasarkan kondisi eksisting yang diamati dan segala potensinya.

\section{KAJIAN LITERATUR}

\section{Tempat Ketiga dan Arsitektur Terbuka}

Tempat ketiga (third place) merupakan sebuah tempat berkegiatan di luar dari keseharian di tempat tinggal dan tempat bekerja (Oldenburg, 1989). Tempat pertama bersifat privat, tempat kedua merepresentasikan nilai publik dan privat, dan tempat ketiga menjadi pemberi nilai publik sepenuhnya (Sutanto, 2020). Kehidupan di Kawasan Penjaringan, dan di perkotaan pada umumnya menjadi semakin bersifat hedonis dan individualis seiring perkembangan teknologi dan kemudahan lainnya. Bahkan, berdasarkan sebuah hasil observasi, Generasi Y lebih menggunakan tempat virtual seperti media sosial dan chatting sebagai tempat ketiga mereka ketimbang tempat fisik dimana interaksi langsung antar manusia dapat terjadi (Crick, 2011). Hal ini mengakibatkan implikasi negatif dalam berbagai aspek kehidupan warga kota, sehingga perlu disediakan sebuah wadah yang memenuhi kebutuhan mendasar dari segi sosial dan psikologis bagi warga di perkotaan. Wadah ini bersifat terbuka bagi segala kalangan, dengan 
konsep arsitektur terbuka (open architecture) untuk membentuk komunitas yang dapat berinteraksi dan berkegiatan dengan satu sama lain tanpa memandang status.

\section{Placemaking}

Placemaking merupakan sebuah bentuk upaya kolaboratif oleh warga kota dalam membentuk ruang-ruang publik dengan berdasarkan nilai-nilai yang ada dalam diri setiap individu. Ruangruang publik ini dapat menyediakan apapun yang dibutuhkan bagi setiap orang, karena placemaking dibentuk oleh semua orang yang ada disana. Tolak ukur keberhasilan

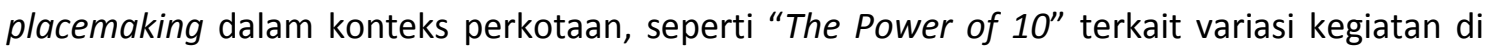
sebuah tempat, mendukung keberhasilan tempat ketiga sebagai sebuah ruang publik (Project for Public Spaces, 2008).

\section{Proksemik (Proxemics)}

Proksemik merupakan bagian dari studi terhadap komunikasi non-verbal seperti sentuhan, gerakan tubuh, parabahasa, suara, dan struktur waktu (Hall, 1992). Jarak sosial antar orang ini tergantung pada jarak fisik, sama seperti jarak intim dan personal. Setiap jarak sosial mempengaruhi komunikasi antar individu dan kelompok. Hasil dari pengamatan ini dapat diterapkan ke dalam perancangan sebuah tempat ketiga, seperti dengan membuat repetisi program di seluruh bagian bangunan untuk membentuk sebuah keseluruhan yang familiar, serta meminimalisir penggunaan partisi sehingga terjadi kontak sosial antara ruang sirkulasi dengan ruang yang berfungsi yang memberikan kesan kekeluargaan.

\section{Bahasa Pola (Pattern Language)}

Bahasa Pola atau Pattern Language (Alexander, 1977) merupakan kumpulan dari prinsip mengenai bagaimana manusia berinteraksi dengan ruang yang terbentuk. Prinsip-prinsip ini berperan sebagai coding yang memprediksi kebiasaan manusia, seperti dimana dan bagaimana manusia lebih suka untuk berjalan, duduk, tidur, masuk, dan bergerak di dalam dan melalui bangunan, menikmati ruangan atau ruang terbuka, hingga elemen hijau seperti taman. Penerapan Bahasa Pola dapat mengomptimalisasikan lingkungan buatan untuk menghadirkan kehidupan dan rasa kesejahteraan bagi manusia di dalamnya. Setiap pola merefleksikan mode hidup, kebiasaan dan perilaku yang berbeda-beda, dan tergantung pada iklim, geografi, budaya, dan adat istiadat masing-masing. Maka, dalam merancang sebuah tempat ketiga sebagaimana yang diinginkan, dapat dipilih beberapa pola sebanyak yang dibutuhkan, dengan memperhatikan gaya hidup dan kebiasaan orang-orang di lingkungan yang menjadi konteks perancangan, lalu mengaplikasikannya ke dalam situasi tersebut.

\section{METODE}

Dalam melakukan perancangan, proyek ini menggunakan beberapa langkah pendekatan, yaitu:

\section{Pengumpulan Data}

Data yang diambil adalah karakteristik kawasan serta penggunanya, dan dikumpulkan dengan melakukan pemetaan serta observasi secara langsung. Data yang diperoleh dianalisis sebagai dasar perancangan proyek. Kunjungan ke Kawasan Penjaringan dilakukan pada bulan Februari 2020, dengan waktu pengamatan di sore hari. Lokasi pengamatan berada di pusat Kawasan yang merupakan perbatasan antara Kelurahan Pluit dan Kelurahan Penjaringan, dan batasan pengamatannya adalah radius yang mencakup hingga tiga lapisan jalan, dengan Mal Pluit Junction sebagai acuan utama.

\section{Pendekatan Berbasis Tempat Ketiga}

Pendekatan desain digunakan setelah memahami kawasan, untuk mengarahkan desain berdasarkan karakteristik keberhasilan tempat ketiga oleh Ray Oldenburg. Pemahaman akan 
'arsitektur terbuka' menjadi arah dalam merancang tempat ketiga yang mengusung konsep komunitas terbuka, dan teori placemaking memberikan gambaran mengenai tempat yang akan berhasil digunakan sebagaimana mestinya di konteks perkotaan.

\section{Metode Perancangan Berbasis Perilaku}

Setelah dilakukan pendekatan berbasis tempat ketiga, teori proksemik digunakan dalam membentuk tata letak ruang di dalam bangunan berdasarkan jarak sosial yang memicu interaksi netral di antara para pengguna, dan semua hal tersebut dikombinasikan menjadi ruang-ruang yang terbentuk dengan metode Bahasa Pola. Beberapa pola yang relevan diambil dan diterapkan untuk menghasilkan keruangan yang berfungsi sebagai tempat ketiga dengan baik.

\section{DISKUSI DAN HASIL}

\section{Analisis Lokasi dan Analisis Tapak}

Kawasan Penjaringan terpilih sebagai konteks perancangan setelah dilakukan tinjauan umum terhadap Kota Jakarta dengan pemahaman mengenai tempat ketiga. Lokasi perancangan berada di pusat kawasan yang berada di dekat noda utama Kawasan Penjaringan. Kawasan ini memiliki persentase tempat pertama dan kedua yang relatif dominan (gambar 1). Tapak perancangan dipilih berdasarkan potensi yang terlihat untuk membangun tempat ketiga di lingkungan tersebut, untuk menjawab beberapa tantangan setempat, yakni fasilitas Mal Pluit Junction dan Taman Putra Putri yang tidak berfungsi secara maksimal, padatnya tempat pertama dan kedua, serta pergerakan pedestrian yang kurang efisien.
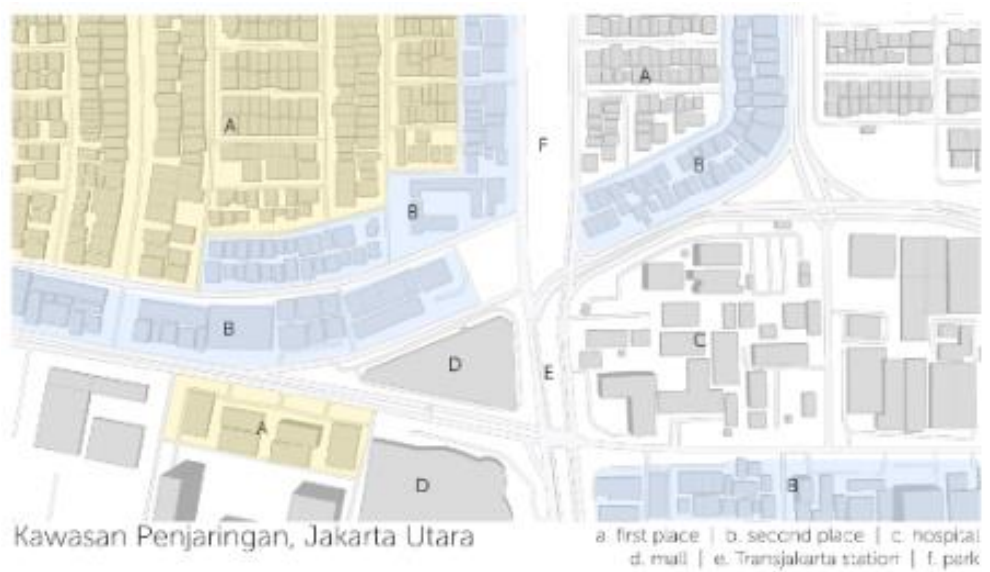

Gambar 1. Peta Fasilitas Kawasan Penjaringan Sumber: Penulis, 2020

\section{Konsep Skywalk dan Jalur Pedestrian}

Sebuah plaza yang dihadirkan pada perimeter dan tengah tapak menjawab kondisi sirkulasi pada level jalan yang secara umum berupa trotoar linear serta zebra cross untuk menyeberang (gambar 2). Pada bagian utara dan selatan tapak, akses masuk pedestrian dibuka mengitari perimeter tapak. Sementara sebuah zebra cross dibuat di bagian timur tapak untuk mempermudah akses dari dan ke Taman Putra Putri. 


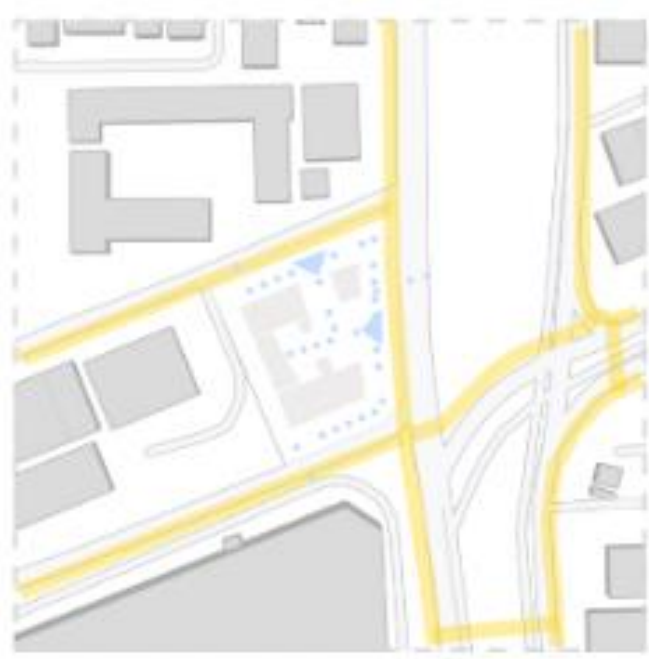

ground pedestrian circulation + access

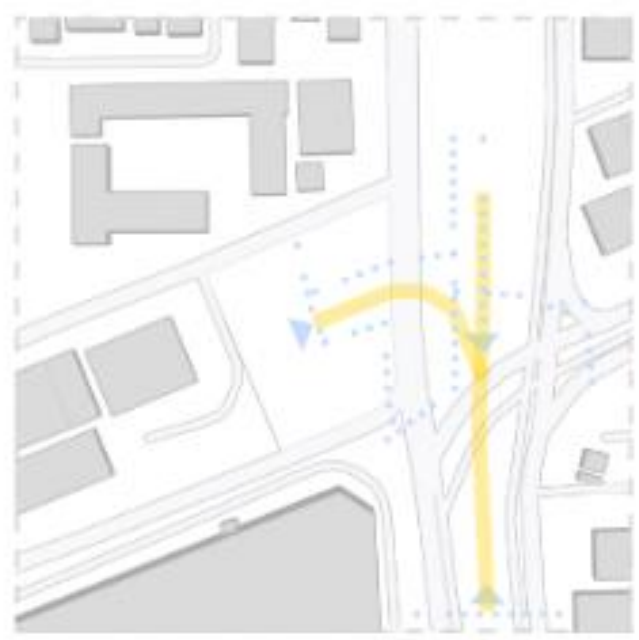

skywalk pedestrian circulation + access

Gambar 2 dan 3. Sirkulasi di sekitar tapak dan proyeksi skywalk Sumber: Olahan Pribadi, 2020

Sebuah skywalk dibuat sebagai ekstensi dari proyek tempat ketiga untuk meningkatkan mobilitas lingkungan, yang secara bersamaan menjawab tantangan minimnya pengguna bagi fasilitas Taman Putra Putri dan Mal Pluit Junction (gambar 3). Skywalk ini memiliki tiga titik akses, yakni dari Taman Putra Putri, dari plaza pada tapak, serta dari Halte Transjakarta Penjaringan untuk membuka arus pergerakan secara maksimal. Titik-titik masuk ini diletakkan di lokasi yang mudah diakses oleh pedestrian, baik dari trotoar maupun zebra cross. Pada tapak, pengguna skywalk dapat memutuskan untuk turun ke plaza atau masuk langsung ke dalam bangunan di lantai dua (gambar 4).

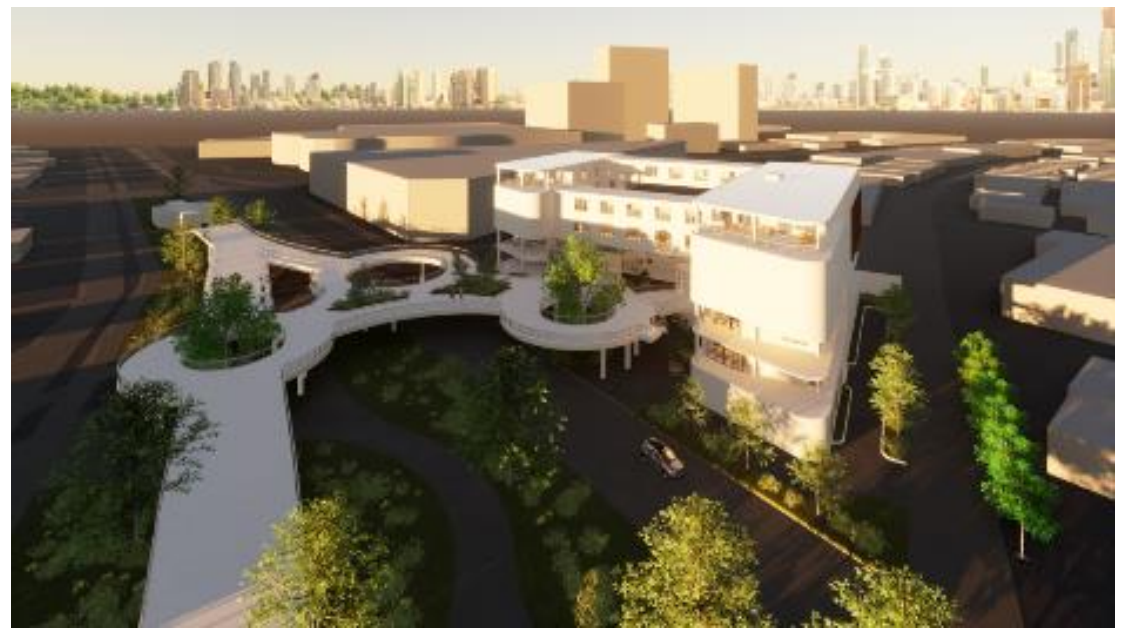

Gambar 4. Perspektif bird eye view dari sisi utara ke arah bangunan dan skywalk Sumber: Olahan Pribadi, 2020

\section{Konsep Bangunan}

Bangunan tempat ketiga yang berada di dalam tapak perancangan memiliki konfigurasi program (gambar 5 dan 6) yang merespons karakteristik warga Kawasan Penjaringan terutama dari segi persentase pekerjaan, serta meresponi informasi yang dikumpulkan mengenai jenis dan persebaran fasilitas kawasan. Selain itu, pemilihan program juga mempertimbangkan kriteria keberhasilan tempat ketiga, aspek komunitas arsitektur terbuka, serta fleksibilitas kegiatan berbasis placemaking. 

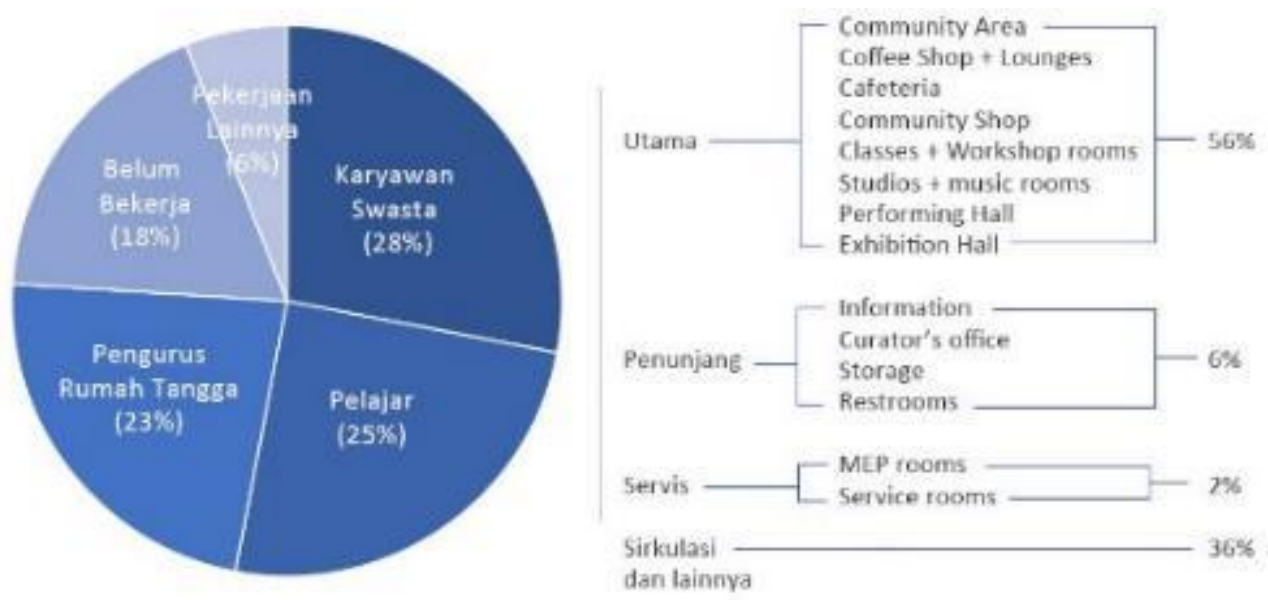

Gambar 5 dan 6. Persentase warga kawasan berdasarkan pekerjaan dan bagan program Sumber: Olahan Pribadi, 2020

Konfigurasi spasial program-program tersebut ditata dengan menggunakan metode Bahasa Pola, yang terpilih karena relevansinya dengan proyek dalam hal menghasilkan ruang berbasis perilaku manusia di ruang publik, baik itu beraktivitas maupun bersirkulasi. Dari 293 pola yang ada, diambil 3 pola umum yang relevan (gambar 7) sebagai acuan dasar perancangan yang di saat bersamaan tidak bersifat terlalu spesifik, untuk menjaga fleksibilitas di tahap pengolahan ruang.
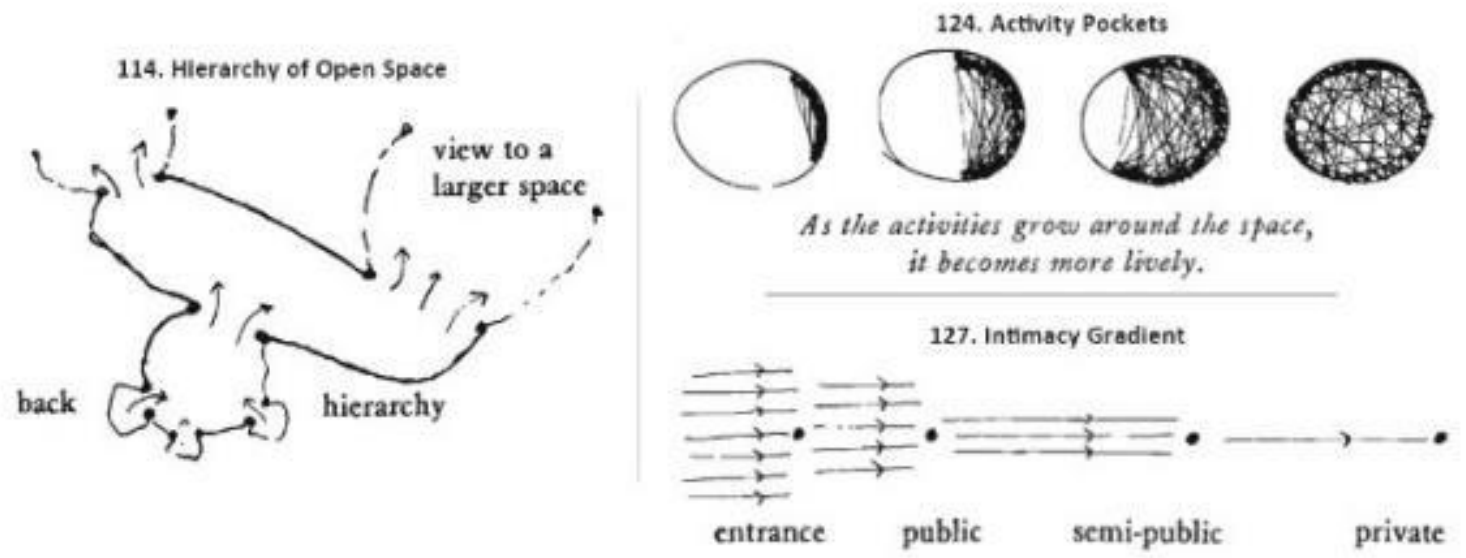

Gambar 7. Pola-pola yang diterapkan ke dalam tapak dari metode Bahasa Pola Sumber: A Pattern Language: Towns, Buildings, Construction, 1977

Pola-pola yang diambil adalah: a. hierarchy of open space (pola 114) yang ketika diterapkan ke dalam proyek, courtyard dan plaza terbentuk dari permainan massa di lantai dasar dan dua untuk memberikan pengalaman bertransisi masuk dan keluar bangunan pada level jalan maupun melalui skywalk, b. intimacy gradient (pola 127) yang membentuk hubungan antara ruang-ruang publik, semi-publik dan privat ditata lapisan-lapisannya untuk memaksimalkan suasana kekeluargaan di dalam bangunan serta memenuhi kebutuhan intimasi program yang berbeda-beda tingkatannya, dan c. activity pockets (pola 124) yang ketika diterapkan, bentukan ruang-ruang diisi dengan program terbuka yang secara mayoritas berupa area berkomunitas untuk menciptakan pojok-pojok aktivitas yang fleksibel di seluruh bangunan. Setiap lantai memiliki konfigurasi yang elemen-elemen dan hirarki yang sama, dengan variasi besaran dan letak ruang-ruang (gambar 8 ). 


\section{SCHEMATIC ZONING}

Methodology adapled fom Chriatopher Alexanders Paflem Language. a hierachy of space, b intimacy gradient, c) pockets of activity

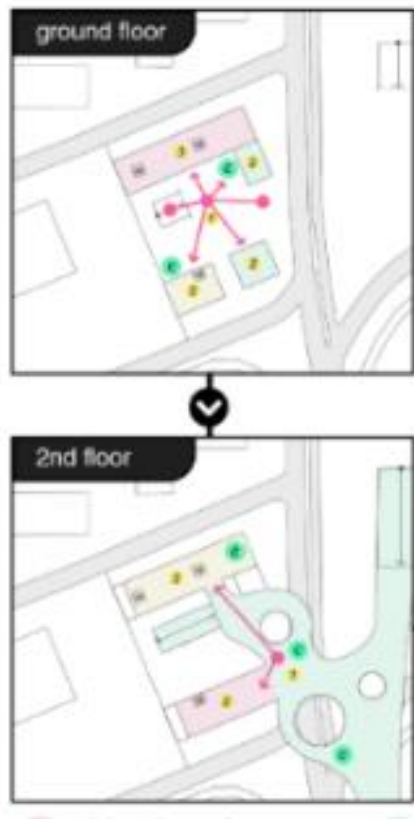

colaborative performance
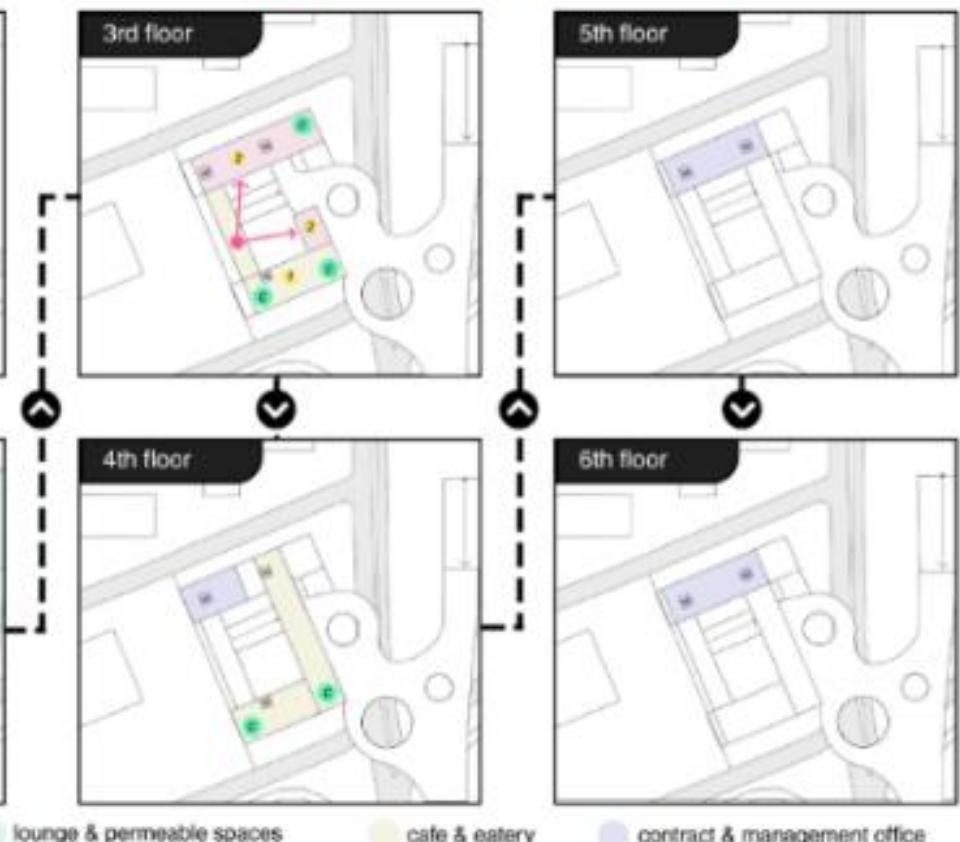

contract 8 management ctfice

Gambar 8. Penerapan tiga prinsip Bahasa Pola menjadi zonasi dasar di dalam tapak Sumber: Olahan Pribadi, 2020

Program-program dalam proyek tempat ketiga di Kawasan Penjaringan ini mengundang berbagai lapisan warga Kawasan Penjaringan dan pengunjung dari luar kawasan untuk bernaung dan berkegiatan bersama, dengan jam-jam aktivitas yang berbeda-beda, seperti makan pagi bersama di cafetaria, dan menikmati live music di jam-jam setelah pulang kerja (gambar 9). Bangunan ini yang secara keseluruhan memberikan kebebasan bagi setiap pengunjung untuk berkegiatan di zona yang diinginkan juga memperbolehkan mereka untuk membawa instrumen musik dan memainkannya, baik di zona terbuka atau tertutup. Kegiatan bermusik ini diharapkan dapat menjadi faktor yang dapat membantu terjadinya interaksi sosial di antara para pengunjung.

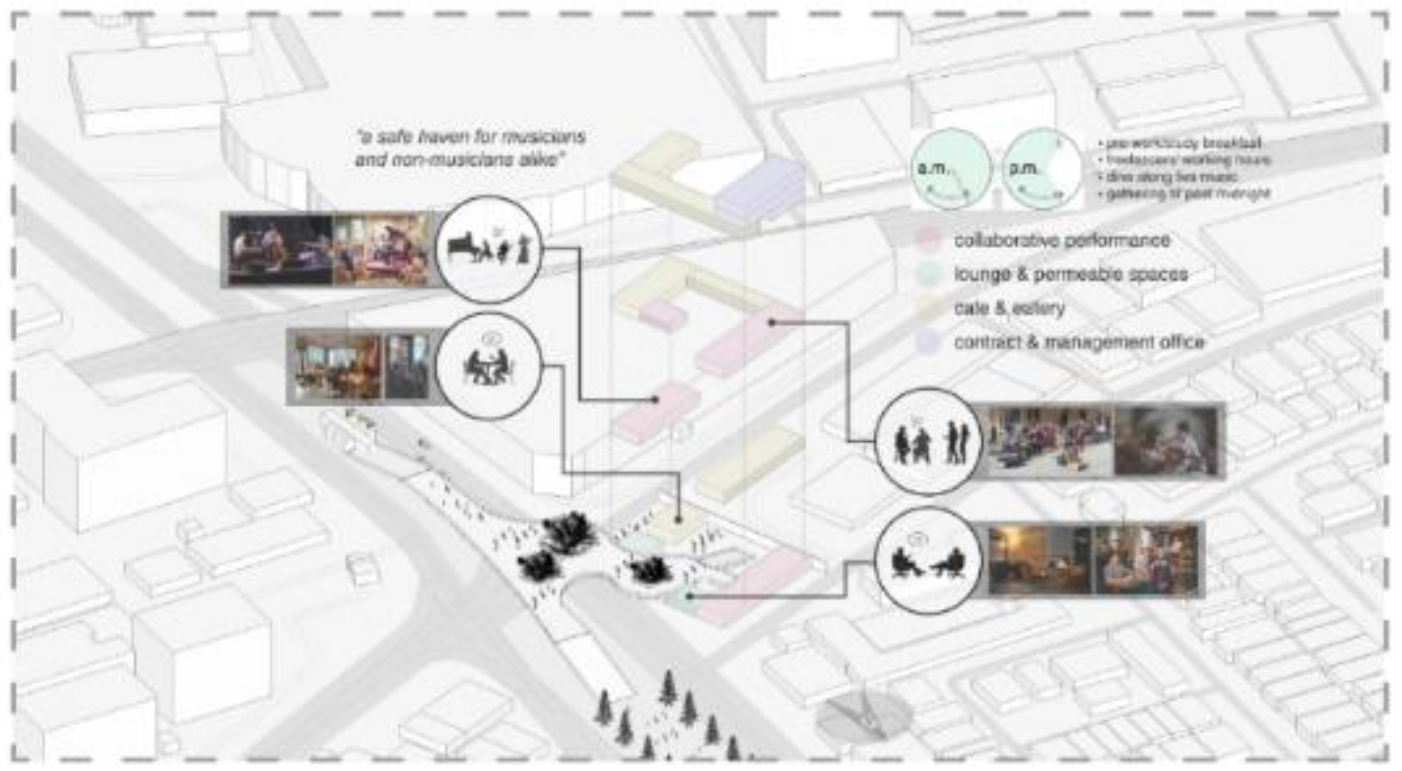

Gambar 9. Program kegiatan yang ada di dalam tapak Sumber: Olahan Pribadi, 2020 
Pengolahan ruang interior serta tata letak furnitur dilakukan dengan menerapkan pendekatan proksemik, dimana perbedaan jarak antar individu atau kelompok dapat mendorong terjadinya interaksi sosial (gambar 10).

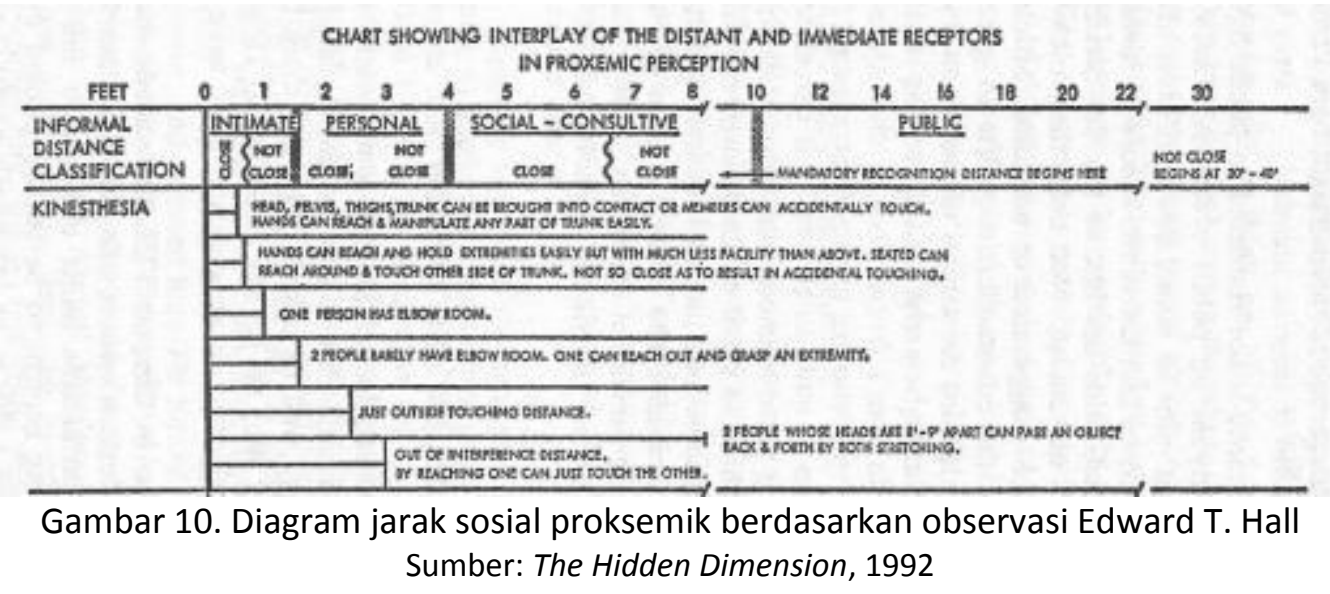

Pada setiap lantai bangunan, jalur-jalur sirkulasi dibagi menjadi beberapa zona, yakni zona jalur yang tidak terpengaruh dengan ketertarikan untuk berinteraksi, dan zona yang terpengaruh. Penerapan proksemik ini berperan dalam menciptakan kelompok-kelompok ruang yang intim dan berelasi dengan jalur sirkulasi yang melewatinya (gambar 11).

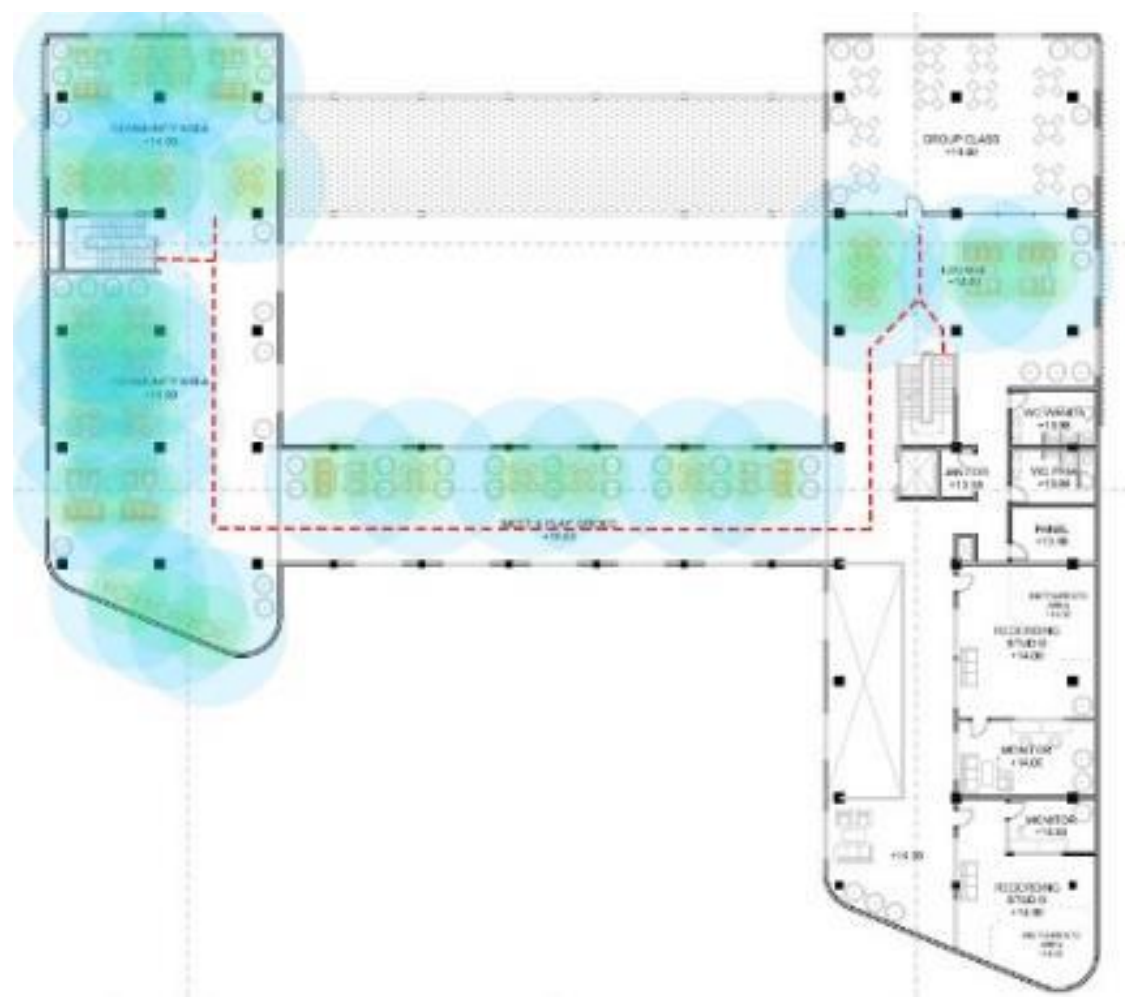

Gambar 11. Simulasi penerapan jarak sosial proksemik pada lantai Lima Sumber: Olahan Pribadi, 2020

Tampilan luar bangunan (eksterior) dibentuk dengan pemilihan material serta bentukan massa yang menghargai tipologi lingkungan setempat (gambar 12). Kesan sederhana ingin diberikan untuk membuat suasana yang hangat bagi setiap pengunjung. Pengalaman masuk dari plaza ke dalam bangunan dengan melewati courtyard yang intim memberikan kesan transisi atau sekuens perjalanan yang unik dengan konsep denial and reward (gambar 13). 

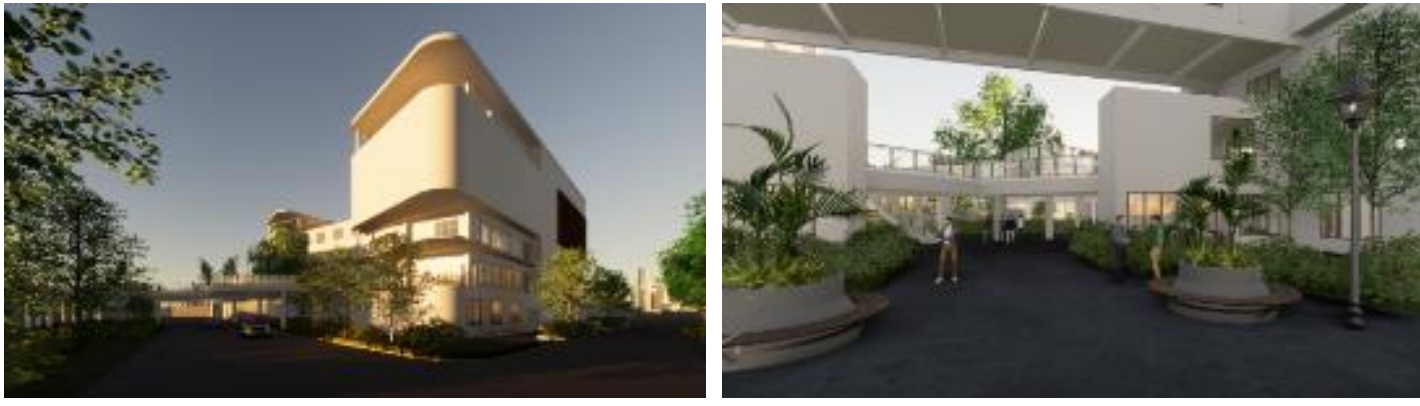

Gambar 12 dan 13. View pada level jalan dari sisi utara dan view ke arah courtyard Sumber: Olahan Pribadi, 2020

Setiap bagian bangunan, termasuk pada lantai dasar, memberikan pengalaman yang berbedabeda, sehingga pengunjung diharapkan merasa ingin bereksplorasi di dalam keseluruhan proyek.
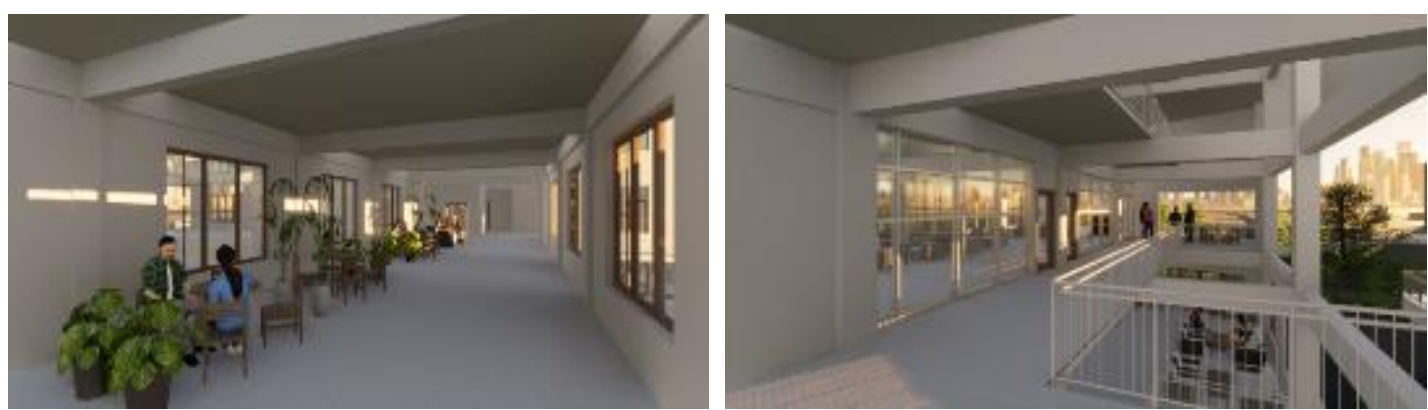

Gambar 14 dan 15. Suasana jembatan penghubung dan suasana di lantai ketiga Sumber: Olahan Pribadi, 2020

Seperti yang terlihat pada gambar 14 dan 15, suasana ruang yang ingin dicapai adalah suasana yang hangat dan sederhana untuk menciptakan wadah yang netral dan tidak berlebihan sebagai sebuah tempat ketiga yang mengusung konsep "ruang tamu" yang melayani warga Kawasan Penjaringan yang berbeda-beda latar belakangnya.

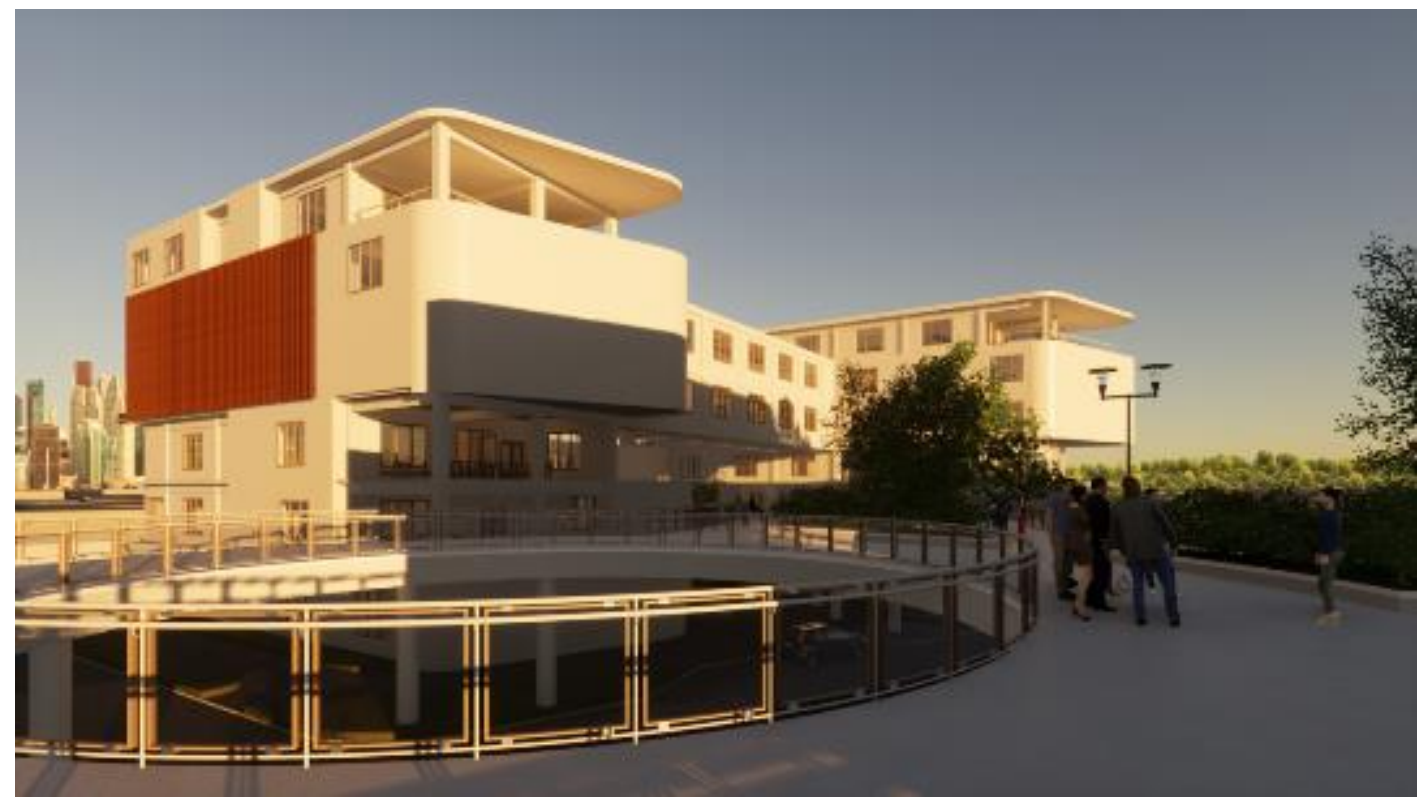

Gambar 16. View dari skywalk ke arah bangunan pada sore hari Sumber: Olahan Pribadi, 2020 
Proyek ini yang mencakup bangunan serta ekstensi skywalk-nya diharapkan tidak hanya sekedar memenuhi kebutuhan mendasar akan tempat ketiga bagi warga kawasan ini, tetapi juga dapat menjadi destinasi yang memberikan pengalaman yang unik di dalam kehidupan perkotaan Kota Jakarta.

\section{KESIMPULAN DAN SARAN Kesimpulan}

Berdasarkan hasil studi dan analisis yang telah dilakukan dalam perancangan proyek tempat ketiga di Kawasan Penjaringan ini, dapat ditarik kesimpulan bahwa sebuah tempat ketiga bukanlah sesuatu yang bersifat baru dan opsional bagi perkotaan, tetapi merupakan elemen integral di dalam keseharian warganya. Tempat ketiga ini berfungsi sebagai wadah berkomunitas dan berkegiatan di luar kesibukan sehari-hari sebagai kebutuhan psikologis mendasar setiap individu. Berdasarkan studi pendekatan berbasis tempat ketiga serta penerapan metode berbasis perilaku yakni Bahasa Pola dan proksemik ke dalam perancangan proyek Tempat Ketiga Berkonsep Ruang Tamu bagi Kawasan Penjaringan dengan Ekstensi Skywalk sebagai Prasarana Pendukung Mobilitas Pedestrian pada Skala Lingkungan ini, terbentuk wadah yang diharapkan dapat melayani masyarakat Kawasan Penjaringan. Bangunan tempat ketiga ini mengusung konsep ruang tamu dengan tema musik sebagai pengikat, dimana warga Kawasan Penjaringan ataupun pengunjung dari luar kawasan dapat datang untuk bermain musik bersama, berkomunitas, dan mengambil sejenak istirahat dari kesibukan mereka sehari-hari. Akhir kata, proyek ini diharapkan dapat berfungsi sebagai tempat ketiga yang baik bagi Kawasan Penjaringan, serta dapat menginspirasi dibangunnya tempat ketiga di kawasan-kawasan lainnya.

\section{Saran}

Proyek perancangan ini tentunya masih dapat dikembangkan lebih lanjut, seperti keruangan di dalam tapak sebagai tempat ketiga dan desain skywalk sebagai ekstensi dari tempat ketiga yang masih perlu ditinjau kembali agar dapat berfungsi secara lebih maksimal.

\section{REFERENSI}

Alexander, C. (1977). A Pattern Language: Towns, Buildings, Construction. Oxford: Oxford University Press.

Badan Pusat Statistik. (2019). Kecamatan Penjaringan dalam Angka 2019. Jakarta: Nario Sari.

Crick, A. P. Dr. (2011). Rethinking Oldenburg: Third Places and Generation Y in a Developing Country Context. International CHRIE Conference-Refereed Track. 7.

De Certeau, M. (1988). Practice of Everyday Life. Berkeley: University of California Press.

Hall, E. T. (1992). The Hidden Dimension. Gloucester: Peter Smith Pub.

Mehr, S. A. et al. (2019). Universality and diversity in human song. Science, 366(6468), eaax0868.

Oldenburg, R.. (1989). The Great Good Place. New York: Paragon Books.

Project for Public Spaces. (2008). What is Placemaking?. Diakses pada tanggal 13 Februari 2020, dari https://www.pps.org/article/what-is-placemaking

Sutanto, A. (2020). Peta Metode Desain. Jakarta: Universitas Tarumanagara.

Tuan, Y. (1977). Space and Place. Minneapolis: University of Minnesota Press. 